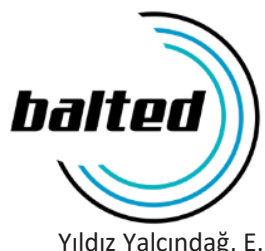

Balkanlarda Türk Dili ve Edebiyatı Araştırmaları

Studies on Turkish Language and Literature in the Balkans Cilt 3/Sayı 1/Kış 2021 - Volume 3/Issue 1/Winter 2021

ss-pp: 39 - 52

Yıldız Yalçındağ, E. (2021). Üsküp’te Türkçe Eğitimi ve Türkçenin Genç Nesil Tarafından Öğrenilmesi Üzerine. Balkanlarda Türk Dili ve Edebiyatı Araştırmaları, 3(1), 39-52. DOI: 10.47139/balted.836756

\title{
Üsküp’te Türkçe Eğitimi ve Türkçenin Genç Nesil Tarafından Öğrenilmesi Üzerine
}

On Turkish Education in Skopje and its Learning by Young Generation

\section{Elifnur YILDIZ YALÇINDAĞ*}

\begin{abstract}
Öz
Üsküp, farklı etnik grupların yaşadığı Osmanlı mirası bir şehir olma özelliğini taşımaktadır. Bu etnik grupların içinde Makedon, Arnavut, Türk, Sırp, Boşnak, Ulah, Roman vd. milletler yer almaktadır. Bu etnik gruplar birbirilerinin dillerinden ve kültürlerinden etkilenerek dayanışma hâlinde yaşamaktadırlar. Üsküp'te Türkçe eğitimi veren çeşitli okullar bulunmaktadır. Bunlardan "Tefeyyüz" isimli okulda, geçmişten günümüze dek Türkçe eğitimi verilmektedir. Üsküp Merkez ve Üsküp’e bağı köylerde yaşayan Türkler, çocuklarının Türkçe eğitim alabilmesi için çeşitli zorluklara göğüs gererek bu okulda eğitim almalarını sağlamışlardır. Çalışmamızda genç neslin Türkçe öğrenmesi hususu çeşitli maddelere dayandırılmıştır. Bunlardan biri ve en güçlüsü, çocukların 1. Sınıftan 9. Sınıfa kadar Türkçe eğitim veren okullara gitmesidir. Bir diğer madde, bazı Türk ve Arnavut aileler çocuklarının Türkçeyi öğrenebilmesi için, evde Türkçeden başka bir dil konuşmamaktadır. Bir diğer madde de bize garip gelen ve göz ardı ettiğimiz; fakat Türkçenin öğrenilmesinde çok büyük bir katkısı olan maddedir. Bu da, Türk televizyon dizilerinin Türkçenin öğrenilmesi üzerindeki etkisidir.
\end{abstract}

Anahtar Kelimeler: Kuzey Makedonya, Üsküp, Tefeyyüz, Üsküp’te Türkçe eğitimi, Türk televizyon dizileri.

\begin{abstract}
Skopje is a city, which has Ottoman heritage and embraces different ethnicities inside. These ethnicities are Macedonians, Albanians, Turks, Serbians, Bosnians, Wallacks, Gypsies etc. They live in a harmony together by affecting languages and cultures of each other. In Skopje, there are several schools where the education language is Turkish. Among them, one school with the name "Tefeyyüz" has been teaching students in Turkish language since the past times. Turkish people living in city center and surrounding villages provide their children take Turkish education in the school despite all the challenges. In this study, the subject of learning Turkish language by the young generation in Skopje is taken into account by various aspects. One of those and the strongest one is that children go to schools which give the education in Turkish language from first to nine grades. Another aspect is that Turkish and Albanian families do not speak any other languages except Turkish in their houses to provide their children
\end{abstract}

\footnotetext{
* Öğr. Gör., Kırklareli Üniversitesi, Rektörlük, Türk Dili Bölümü, elifnuryldz023@gmail.com, ORCID: 0000-0003-3463-2500
} 
to learn it. Also another aspect is the one which seems quite unusual to us and that is why we ignore it, however, it has a huge contribution to learning Turkish language. It is the effect of Turkish television series on learning Turkish.

Keywords: Northern Macedonia, Skopje, Tefeyyüz, Turkish education in Skopje, Turkish television series.

\section{Giriş}

Üsküp, 1389 yılında Yiğit Mehmet Paşa tarafından Osmanlı topraklarına katılmıştır. Osmanlı topraklarına katılmadan önce Üsküp, miladi yedinci asırlarda Slavların saldırılarına maruz kalmış, daha sonraları Sırplar tarafından işgal edilmiş, ardından birkaç defa Bizanslıların ve Sırpların idaresine geçmiştir (Asım, 2004, s. 55).

“Osmanlı Devleti'nin topraklarına kattığı Üsküp, 1689 yılında Avusturya tarafından kuşatılarak ele geçirilmiştir. İşgalden sonra ortaya çıkan veba hastalığını bahane eden Avusturya kumandanı Üsküp'ü tamamen yakmış, askerlerini de Vodana bayırlarına çıkarmıştır" (Asım, 2004, s. 55). Bu yangın sebebiyle Osmanlı dönemine ait birçok tarihi eser tamamen harap olmuştur. Bu eserler ileriki dönemlerde tekrardan inşa edilmiştir. 1690-91 yılında Hacı Selim Giray ve komutasındakilerle Üsküp, Avusturya'dan geri alınmıştır. Geri alınmasından 1912 Sırp işgaline kadar 227 yıl Osmanlı hâkimiyetinde kalmıştır (Asım, 2004, s. 60).

Kuzey Makedonya'nın başkenti olan Üsküp, geçmişten günümüze birçok etnik grubu bünyesinde barındırmıştır. Günümüzde bu etnik gruplar içerisinde ağırlıklı olarak Makedonlar, Arnavutlar ve Türkler yer almaktadır. Daha az bulunmakla birlikte Boşnaklar, Sırplar, Romanlar ve Ulahları da bu etnik grubun içinde gösterebiliriz. Üsküp'te yaşayan bu topluluklar geçmişte olduğu gibi günümüzde de birbirinin dillerinden, kültürlerinden, âdet ve geleneklerinden etkilenmektedirler. Mesela Üsküp'te Türkçe konuşan bir Türk'ün dilinde Sırpçadan, Makedoncadan ve Arnavutçadan geçmiş kelimelere rastlamaktayız. Bununla birlikte Makedonca ve Arnavutçada da Türkçenin etkisi göze çarpmaktadır.

“1389'dan itibaren Osmanlı'nın topraklarına kattığı Üsküp'e Anadolu'dan getirilen Türkler yerleştirilmiştir. Üsküp, Balkan yarımadasının merkezi olarak, daha 14. Asırda Türk halkının önemli bir bölümünü cezbetmiştir. Bu halkın çoğunluğu zanaat, tarım ve ticaretle uğraşmıştır. Türk dalgası 15. Asırda yoğunlaşmıştır. Timur'un istilasından sonra, Osmanlı Devleti'nin merkezi Rumeli'ye taşınmıştır. Buralara Anadolu'dan gelen yeni muhacirler yerleşmiştir" (Tufan, 1996, s. 7). Günümüzde burada yaşayan Türklerin bir kısmı Konya'nın Karaman bölgesindeki Karamanoğlu Bey ve himayesindekilerden olduğunu iddia etmektedir. Böylece Üsküp'teki Müslüman nüfus oranı artmış ve Türkçenin konuşulduğu alan biraz 
daha genişlemiştir.

Üsküp, geçmiş dönemlerden beri ticaretin göz bebeği konumunda olan bir şehirdir. Tarihten beri mevcut olan Türk Çarşısı ve Bit Pazarı'yla Üsküp, çevre Balkan ülkelerinin alışveriş yapmak için sıkça uğradıkları bir şehir olma özelliğini taşımaktadır.

"Şehrin büyüklüğü, 17. Yüzyılın sonuna doğru yapılan Avusturya-Osmanlı büyük savaşını izleyen Avusturyalı muhabirlerin yazılarında kaydedilmiştir. Bu yazılarda, güzelliği ve konutlarının sayısı (10-12.000) ya da ahalisinin sayısına göre (yaklaşık 60.000) Üsküp, Prag ile kıyaslanmıştır" (Zdraveya, 1983, s. 95). Osmanlı Dönemi'nde Üsküp, Türkçenin yaygın olarak konuşulduğu bir şehirdir. Bunun en önemli sebeplerinden biri, alışverişin uğrak mekânı olan kentin Türk Çarşısı ve Bit Pazarı'na sahip olmasıdır. Burada Türkçe bilmeyen esnaf yok denecek kadar azdır. Günümüzde de Türkçe bilmeyen esnafla nadir karşılaşmaktayız. Türkçe bilen kişi, Üsküp halkının deyimiyle "Kasabalı" olarak isimlendirilmektedir. Bu ifadeden de Türkçe bilmenin adeta bir asalet göstergesi olarak algılandığı görülmektedir.

“Makedonya Devlet Istatistik Ofisi (Државен завод застатистика) (2005)'ne göre 2002 yılında yapılan son sayımlarda Kuzey Makedonya Cumhuriyeti'nin toplam nüfusu 2.022.547'dir. Türklerin sayısı ise 77.959'dur. Üsküp'ün toplam nüfusu 506.926, kendini Türk olarak ifade edenlerin sayısı ise 8595'tir. Buna göre Kuzey Makedonya Türklerinin \%11'i Üsküp'te yaşamaktadır" (Ahmed, 2014, s. 2). Bu oran bize, Kuzey Makedonya'da yaşayan Türklerin büyük bir kısmının Üsküp'te yaşadığını göstermektedir.

2019 Temmuz-Ağustos ayında derleme yaptığımız kaynak kişilerin ifadelerine göre; Üsküp'te ve Kuzey Makedonya'daki bazı Türkler yapılan son nüfus sayımında, Kuzey Makedonya Cumhuriyeti'nin yaptığı baskı ve haksızlıklardan dolayı kendilerini nüfusa Arnavut olarak kaydettirmişlerdir. Böylece Arnavutların nüfus oranı fazla gösterilmiştir. Bu, gözlemlerimize göre güçlü olanla bir olup ümmet bilinciyle ayakta kalabilmek ve bazı vatandaşlık haklarından yararlanabilmek için Türkler tarafından izlenilmiş bir politikadır. Aslında bu düşünce, onların nüfus oranlarının az görünmesine ve böylece Türkçe eğitim haklarının elinden alınmasına sebep olmuştur.

"Balkan savaşları döneminde 240.000 Türk, çeşitli olumsuz uygulamalar sonucunda göç etmek zorunda kalmıştır" (Abbas, 1999, s. 284). 1912 Sırp işgalinden itibaren Türk nüfusun çoğunluğu zorlanarak, hatta işkence edilerek göçe mecbur bırakılmıştır. Bu işgal sonucunda büyük sayıda Türk göçü meydana gelmiştir. 1948 yılında meydana gelen "Yücel Olayı" neticesinde Yugoslavya'dan büyük bir Türk göçü olmuştur. Makedonya'daki Türk nüfusu bu olayla azınlık konumuna gelmiş, 
Türkçe eğitim hakkı burada kalan Türklerin ellerinden alınmıştır.

Yücel olayı tarihte "Aydın Göçü" olarak da bilinmektedir. Türkleri milliyetçi düşünceyle bir arada tutmak isteyen gönüllüler Yücel teşkilatını kurmuşlardır. Teşkilat üyeleri, Yugoslavya tarafından 1947 yılında Yasadışı örgüt statüsüne alınmasıyla birlikte idama mahkûm edilmişlerdir (Çelik, 2013, s. 273). Bu Olay, Tito döneminde Türkiye Cumhuriyeti yetkililerinin 1950'lerin başında Yugoslavya ile bir "Serbest Göç" Antlaşması imzalamasıyla etkisini göstermiştir. Bu antlaşmayla Türkiye Cumhuriyeti yetkilileri Makedonya'da ve Yugoslavya'da yapılan Türk göçünü teşvik etmiştir. Bu teşvikle Makedonya'dan 296.000, Kosova, Sancak, Bosna ve Karadağ'dan ise 500.000 'den fazla Türk göç etmiştir. Bu sırada yüzlerce Türk öğretmeni, doktoru, şair, yazar, gazeteci ve bilim insanı da göç etmiştir. Makedonya'da kalan Türkler, öğretmensiz, doktorsuz, âlimsiz, münevversiz kalmıştır. Yücel Olayının neticesinde dört Türk münevveri idam edilmiş, onlarca Türk ise ömür boyu veya yıllarca hapse mahkûm edilmişlerdir. Bu olay, Makedonya ve Yugoslavya Türklüğüne büyük bir darbe indirmiştir" (Hamzaoğlu, 2000, s. 323346).

Bu çalışmamızda, Üsküp'te geçmişten günümüze Türkçe Eğitim ve Öğretimin yapıldığı okullar genel çerçevede ele alınmıştır. Söz konusu okullar, Osmanlı Dönemi'nde açılan medreseler ve 1944'ten itibaren kurulan okullar olmak üzere iki ayrı paragraf hâlinde incelenmiştir. Daha sonra günümüzde Türkçe eğitim veren okullar incelenmiştir. Bu okulların en önemlisi olarak kabul edilen "Tefeyyüz" ün geçmişteki durumu ve günümüzdeki hâli hakkında bilgi verilmiştir. Türkçe Eğitim ve Öğretim hakkında genel olarak bilgi verildikten sonra Üsküp'e bağlı köylerde yaşayan yetişkinleri Makedon dilini konuşan Türk topluluklar ele alınmış, söz konusu toplulukların Türkçe eğitim ve öğretim hakkını elde etmek için verdikleri mücadeleden bahsedilmiştir. Daha sonra Türk televizyon kanallarını izlemenin Türkçe öğrenime katkısı ayrı bir başlık altında incelenmiştir. Söz konusu tüm hususlar ele alındıktan sonra makale, sonuç başlı̆ı altında neticelendirilmiştir.

\section{Üsküp'te Türkçe Eğitim ve Öğretim}

Zerrin Bedri Abbas'a göre Kuzey Makedonya'nın Osmanlı Devleti'nin hâkimiyetinden 1912 yılında çıkışından sonra Türklerin eğitim sorunları da başlamıştır. Türkler, çocuklarını Sırp okullarına göndermek istemedikleri için tepkiler yoğunlaşmıştır. Türkler, 1914 yılında Türkiye ile Sırbistan arasında yapılan anlaşmaya riayet edilmesini istemişlerdir. Bu doğrultuda Sırp eğitim kurumları siyasi taktik içeren bir uygulamayla, Türk okullarında Türk dilinde din dersine girecek olan öğretmenlerin Türkçe derslerine de girmesine karar vermiştir; ancak din dersini veren öğretmenlerin Türkçe derslerinde yeterli bilgiye sahip olmaması 
Türkçenin öğretimini zorlaştırmıştır (284-285). Böylece Sırp yönetiminin izlediği siyasi propagandanın ilk adımı atılış ve bu adım Türkçenin öğretiminde olumsuz etkiye sebep olmuştur.

Sırp-Hırvat-Sloven Krallığı döneminde okullarda Türkçe eğitimin engellenmeye başlanmasıyla Türk nüfusunun eğitimsiz kalması gibi bir sorun ortaya çıkmıştır (Abbas, 1999, s. 284).

Sırp-Hırvat-Sloven Krallığının Türkçe anadili öğretiminde uyguladığı birçok engelleyici politika sebebiyle Türkler, çocuklarını okullara gönderememiştir. Bugariç'e göre, Bunun sonucunda da Türk çocukları, uzun süre mahalle ve sıbyan mekteplerinde eski yazı ile öğrenim görmüşler, plansız ve programsız okutulmuşlardır. Bu durum, 1944'e kadar sürmüştür (182).

Türkler, Latin harfleriyle anadilinde okuma hakkını 1944'te kazanmışlardır (Bugariç, 1997, s. 182). Böylece Kuzey Makedonya Cumhuriyeti'nde Türkler eğitim hakkını geri almışlardır. Bu hakkın geri alınmasıyla birlikte Türkler çeşitli okullar- da, kısıtlı da olsa Türkçe eğitim almaya başlamışlardır.

\section{Üsküp’te Geçmişten Beri Türkçe Eğitim Veren Okullar}

Osmanlı döneminden itibaren Üsküp'te Türkçe eğitim veren çeşitli medreseler açılmıştır. Bu medreselerden bazılarının isimlerini zikretmek gerekirse; Üsküp'ü fetheden Yiğit Paşa tarafından 1397 yılında yaptırılan "Meddah Medresesi", 1438 yılında yaptırılan daha sonra kapatılan ve yerine ulema meclis binası olarak açtırılan "Hünkâr Medrese", Yiğit Paşanın oğlu İshak Bey tarafından yaptırılan "Alaca Medrese", 1460 yılında yaptırılan “isa Bey Medresesi", 19. Yüzyılda yaptırılan "Hümaşa Sultanî", 1890 yılında Faik Paşa döneminde yaptırılan "Ünasi Rujdiye" Sırp-Hırvat-Sloven krallığı döneminde "Kralica Mariya" adıyla değiştirilmiştir. Bu okuldan mezun olan kız öğrenciler öğretmen olma hakkına sahip olmuşlardır. 1903 yılında yaptırılan "Rujdiye Askerî Mektebi", 1903 yılında açılan ve birçok bilim adamı ve siyasetçinin yetiştiği "IV. İdadiye” (Abbas, 1999, s. 291).

Mücahit Asimov'a göre, Üsküp'teki ilk iptidaî mektepler 1885'ten sonra açılmaya başlamıştır. Bu mektepler; "Faik Paşa" "Yahya Paşa” "Meddah" "Hafız Mahmud" "Şükriye Enas" iptidaîyeleridir. Bu okullarda 60'ı kı, toplam 570 öğrenci öğrenim görmüştür (Asimov, 1983, s. 55-67).

Üsküp İdadisi 1889 yılında eğitime başlamıştır. Diğer adı Sultanî olan okulda 1893 yılına kadar 61 öğrenci varken 1900 yılında bu sayı 283'e çıkmıştır (Kodoman, 1991, s. 119-120).

Üsküp’te doğup büyüyen meşhur Türk şair ve münevverimiz Yahya Kemal 
de Üsküp İdadisinde eğitim görmüştür. Ertuğrul Karakuş’a göre İdadi, günümüzde mevcut olmayan bir Osmanlı eseridir. Eser, Islahhane Parkı olarak da bilinen Üsküp Şehir Parkı yakınlarında bulunmaktaydı. Bu bina 1963 yılına kadar Öğretmen Okulu olarak faaliyet görmüştür (Karakuş, 2018, s. 100).

XIX. yüzyılın sonlarına doğru Üsküp'te çeşitli zanaat dallarında usta, işçi, teknisyen yetiştiren bir Sanayi Mektebi açılmıştır. Bu okulun eğitim süresi beş yıldır ve diğer devlet okulları gibi yatılı ve ücretsizdir. Bu okul 1912 yılına kadar faaliyetini sürdürmüştür (Eren, 1968, s. 41-47).

1910-1912 yılları arasında eğitime olan ilgisizlik yüzünden ülkede okuma yazma bilmeyenlerin oranı artmıştır. Bazı bölgelerde bu oran \%90'a kadar ulaşmıştır. Balkan savaşlarından sonra ülkede verilen Türkçe eğitim iyice azalmıştır. Balkan savaşından sonra Türk okulları tamamen kapatılmış ve bu okullarda eğitim gören çocuklar, Sırp okullarına gitmeye mecbur bırakılmıştır (Hasan, 1998, s. 30).

"İsa Bey Medresesi" daha çok dinî eğitim verilmiştir. 1924'te açılan "Büyük Kral Aleksander Medresesi"nde dersler sadece Sırpça verilmiştir. Medresede eğitim 8 yıl sürmüştür ve 1 . Sınıftan 4 . Sınıfa kadar Türkçe eğitim alınabilmiştir (Abbas, 1999, s. 286).

Arif Ago'ya göre 1947 yılından itibaren ilkokul öğretmen kadrosu yetiştirilmesi için Makedonca eğitim veren 3, Arnavutça eğitim veren 1 ve Türkçe eğitim veren 1 öğretmen okulu Üsküp, Manastır ve İştip'te kurulmuştur.

1996 yılında Üsküp’te anaokulu olarak eğitim veren sadece iki okul vardır. Bunlar: "Bratstvo i Edinistvo" ve "Oktomvri" okullarıdır. Bu okullarda sadece birer sınıfta Türkçe eğitim verilmiştir.

Orta Öğretimde 1971-72 yılında açılan "Tsvetan Dimov"da Türkçe eğitim verilmiştir. Bunun yanında "Üsküp Yosip Broz Tito Lisesi”nde de bir dönem Türkçe eğitim verilmiştir. Günümüzde Yosip Broz Tito Lisesinde her yıl Türkçe eğitim veren iki sınıf açılmaktadır. Bunun yanında Ekonomi lisesi "Tsvetan Dimov"da Türkçe eğitim verilmek üzere bir sınıf açılmaktadır.

Türkçe Yüksek Öğrenimi Üsküp’te “Kliment Ohridski”nin 1976-77 yılında açılmasıyla başlamıştır. "Aziz Kiril ve Metodiy Üniversitesi" Filoloji fakültesinin açılmasıyla "Kliment Ohridski" nin çalışmaları eski değerini yitirmiştir (7-9 ).

Günümüzde Üsküp'te yüksek eğitim derecesinde “Aziz Kiril ve Metodiy Üniversitesi" ve "Uluslararası Balkan Üniversitesi" Türkçe eğitim vermeye devam etmektedir. 
Üsküp “Petar Zdravkovski-Penko” ve Güreler köyünde ilkokulunu bitiren Türk çocukları ya günümüzdeki adıyla "Yaşar Bey" olarak adlandırılan "Yane-Sandanski" ya da "Tefeyyüz"de eğitimlerine devam etmektedirler. Bu okullarda dokuz yıllık Türkçe eğitim verilmektedir. Türk okullarında öğrenci sayısının düşük olma nedenlerinden biri de kimi ebeveynlerin ekonomik, siyasi vb. nedenler yüzünden çocuklarının birinci sınıftan başlayarak Arnavutça veya Makedonca öğrenmelerine müsaade etmiş olmasıdır (Ago, 1996, s. 12). Üsküp'te bulunduğumuz süreçte kaynak kişilerden aldığımız bilgilere göre Arnavutça veya Makedonca öğrenen Türk çocukları öğrenimine Arnavutça veya Makedonca eğitim veren okullarda devam etmiştir. Böylece Türk okullarına olan talep azalmışır.

Söz konusu problemin diğer bir sebebi, Üsküp’te Türkçe eğitim veren iki lise "Üsküp Yosip Broz Tito Lisesi" ve "Tsvetan Dimov" haricinde başka lise bulunmamasıdır. Öğrenci, Makedonca ya da Arnavutça eğitim veren bir liseye gittiğinde dile hâkim olmadığı için zorluk çekmektedir. Bunun bir diğer sebebi de Türkçe eğitim veren okulda okuduktan sonra Makedoncaya ve Arnavutçaya hâkim olmadığı için iş bulamamasıdır. Ayrıca Makedonlar ve Arnavutlar iş alımında kendi ırkından olan vatandaşlarını tercih etmektedirler. Böylece sadece Türkçeye hâkim olan Türkler, iş bulamamakta ve işsizlik yüzünden Türkiye ya da Avrupa ülkelerinden birine göç etmeye mecbur olmaktadır. Türklerin Üsküp, Kuzey Makedonya'dan malını mülkünü terk ederek göç etmesinin en önemli sebeplerinden birisi budur.

2019’un Temmuz ve Ağustos ayları boyunca Üsküp Merkez ve çevresinde yaptığımız saha çalışmasında, Tefeyyüz'ün geçmişten günümüze önemini arttırarak devam ettiren bir okul olma özelliği taşıdığını gözlemledik. Merkezde derleme yaptığımız, daha çok 50'li ve 60'lı yaşlarda olan kaynak kişiler eski Tefeyyüz'de 8 yıllık Türkçe eğitimini tamamlamıştır. Bununla birlikte 30, 40 yaşlarında olan kaynak kişiler eğitimlerini, eski Tefeyyüz yıkıldığı için Gazi Baba Mahallesi'ne inşa edilen yeni Tefeyyüz'de tamamlamışlardır.

Tefeyyüz İlköğretim Okulu, kesin olmamakla birlikte 1884 yılında Osmanlı Devleti tarafından "Tefeyyüz İptidai Okulu" adıyla kurulmuştur. Kuruluş tarihi tartışmalıdır. 1919/20 yılında "Tefeyyüz" bütün diğer okullar gibi yeni kurulan Yugoslavya Krallığı idaresine geçerek "Osman Çikiç" adıyla eğitim-öğretim faaliyetlerini sürdürmüştür. Osmanlı Devleti'nin Üsküp'ten çekilmesinden sonra Tefeyyüz Okulu, Türk azınlık okulu haline gelmiştir (Tefeyyüz, 2019).

"Ştipska" sokağında bulunan okulun içi karanlık ve eğitim için uygun değilmiş. Okulun bulunduğu konumda, maddi imkânları olmayan aileler yaşadığı için mevcut öğrenciler de maddi açıdan zorluk yaşamışlar. Hatta öğrencilerin kitap 
alacak paraları bile yokmuş. Buna rağmen okulun başarısı gayet iyi durumdaymış. Okulda yedi sınıf varmış. Eğitim gören çocukların birçoğu Sırpça bilmediği için her yıl iki hazırlık sınıfı açılırmış. Okul müdürü de o dönemin ünlü yazarlarından Boşnak "Nazif Resuloviç”miş (Kaya, 1999, s. 149).

Okul, 1944 yılından sonra "Tefeyyüz" adını geri alarak faaliyetlerine devam etmiştir. Osmanlı döneminde faaliyete geçen Tefeyyüz Okulu, Sırp Krallığı, Bulgar işgali, Yugoslavya Cumhuriyeti ve Bağımsız Makedonya süreçlerini yaşayarak çevresindeki Türkler ile ayakta kalabilmiş, köklü bir kurumdur (Tefeyyüz, 2019).

TRT Avaz'ın "Devrialem” programında "Üsküp Türklerine Hizmet Veren Tefeyyüz İlköğretim Okulu" ismiyle Tefeyyüz Illköğretim Okulunun tanıtımı yapılmıştır. Bu program, okulun kuruluşunun 132. yılına özel olarak yapılmıştır. Programda; okulun isminin "yükselmek, ilerlemek" anlamındaki feyzden geldiği, kuruluş tarihinin 1884 olduğu, 21 Aralık 1944'ten itibaren Latin harfleriyle eğitimine devam ettiği ve bu tarihin Makedonya Türkleri arasında "Türkçe Eğitim Bayramı" ismiyle Milli Bayram olarak kutlandığı vurgulanmıştır. Tefeyyüz'ün kuruluşunun 133. Yılına özel TRT Türk tarafından "Hayatın İçinden Üsküp/Tefeyyüz Illköğretim Okulu" adıyla bir program yapılmıştır. Programda Tefeyyüz'ün kısaca tarihine değinilmiş, okul öğretmenlerinin görüşleri alınmış, öğrencilerin basketbol, futbol ve müzik alanındaki ülke çapında ve uluslararası alanda başarılarına değinilmiştir. Öğrencilerin spor ve müzik alanındaki başarıları "Yeni Balkan", "Time Balkan" ve "Sabah" gazetelerinde de haber konusu olmuştur (Tefeyyüz, 2019).

Tefeyyüz, "Osman Çikiç" adıyla eğitime devam ederken Sırplar tarafından "Mehmed Sokoloviç" ve "Vuk Karaciç" isimli iki okul Üsküp’te yaşayan Türk çocukları için eğitime açılmıştır. "Mehmed Sokoloviç" isimli okul, Osmanlı döneminde "Iptidai İrfan" olarak bilinen okulun binasında eğitime açılmıştır (Kaya, 1999, s. 149).

Türkçe eğitim veren okullar, 1955 yılına kadar 1. Sınıftan 4. Sınıfa kadar eğitim verirken 1955 'ten sonra sekizinci sınıfa kadar eğitim vermeye başlamışlardır. Açılan okullarda öğretmen kadrosunda eksiklik yaşanmıştır. Öğretmenler, 3 aylık düzenlenen kurslar sayesinde eğitim vermişlerdir. Kurslar Kuzey Makedonya'nın her tarafında düzenlenerek, öğretmenler yetiştirilmiştir. 1944 yılının aralık ayında Üsküp'te öğretmenlik kursları düzenlenmiştir (Abbas, 1999, s. 292). 


\section{Yetişkinleri Makedon Dilini Konuşan Türk Topluluklar ${ }^{1}$}

Saha çalışması yaparken tespit ettiğimiz bir diğer husus, Üsküp'e bağlı Türk toplulukların yaşadıkları köylerdir. Burada yaşayanlar, yetişkinleri Makedonca konuşan topluluklardır. Osmanlıların 1. Balkan Savaşı sonrasında ülkeden ayrıldıkları 1912'ye kadar kendilerini büyük çoğunlukla Türk saymışlardır. Bu Türk toplulukların bir bölümü günümüzde kendini "Müslüman", gittikçe artan bir bölümü Arnavut, bir bölümü de "Türk" saymaktadır (Oran, 1993, s. 118). Üsküp'e bağlı köylerde yaşayan bu topluluklar kendilerine "Türk" demektedirler. Türk olduklarını kabul etmeleri sebebiyle yeni neslin Türkçe öğrenmesini teşvik etmektedirler.

Bu köylerde dikkatimizi çeken bir husus, yaşlı neslin (50,60, 70'li yaşlar) Üsküp Merkez'den gelin gelenler hariç Türkçe bilmemesidir. Bunun sebebi, Tito ve öncesi dönemde okullarda zorunlu olarak Makedonca eğitimverilmesidir. ${ }^{2}$

Kuzey Makedonya devleti bu insanların Arnavut veya Türklere katılmalarını önlemek için çeşitli faaliyetler düzenlemektedir. Örneğin, rejim değişikliğinden sonra işten çıkarılmanın çokça yaşandığı ülkede, tekrar işe girmek isteyen bu Türk topluluklara sadece Müslüman kimliğine sahip olduklarına ilişkin kâğıt imzalatılmaktadır. Ayrıca, devletin kurduğu bir de "Makedon Müslümanları Kültür ve Bilim Ocağı» vardır. Ocağın yöneticisi, Yunanistan'da devletin Pomaklar konusunda söylediklerini hatırlatan bir söylemde bulunmuştur: "Torbeşler yerli halktır, Makedon'dur, ama Osmanlılar tarafından zorla Müslümanlaştııılmışlardır" (Oran, 1993, s. 118).

Üsküp'e bağlı Türk topluluklarının köyleri olan Aşağı Koliçan, Svetova, Pagaruşa, Dırjılovo, Elova köylerinde, yaklaşık 10 yıl öncesine kadar Türkçe eğitim verilmediği için köy sakinleri, çeşitli zorluklara göğüs gererek, çocuklarının Türkçe eğitim almasını sağlamışlardır. Bunun için Üsküp Merkez'de bulunan Tefeyyüz IIIköğretim Okulu'na minibüs kiralayarak çocuklarının zorlu kış şartları altında her gün okula gidiş geliş yaparak Türkçe eğitim görmesini sağlamışlardır. Neyse ki son 10 yıldır bahsettiğimiz bu köylerde Türk öğretmenler tarafından çocuklara Türkçe eğitim verilmektedir. Bu öğretmenler, büyük bir mücadele vererek Tefeyyüz'de 9 yıllık Türkçe eğitim almışlar ve ardından Türkçe yüksek eğitim görmüşlerdir. Bu nedenle yeni nesil, Standart Türkiye Türkçesine yakın bir dille Türkçe

\footnotetext{
${ }^{1}$ Bu topluluklara "Torbeş" de denilmektedir. Baskın Oran'a göre; Kuzey Makedonya'da üçüncü en kalabalık Müslüman azınlık Torbeşlerdir. Sayıları 35.000 ile 100.000 arasında olduğu söylenen bu Müslüman halk, bir düşünceye göre Pomakların Kuzey Makedonya'daki adı, bir düşünceye göre de Makedonya'daki Müslüman Slavlara verilen isimdir (116-117).

${ }^{2}$ Daha önceki neslin Türkçe bildiği, Pagaruşa köyü civarındaki Türkçe beyit yazılı mezar taşlarından anlaşılmaktadır.
} 
konuşmaktadır. Bu Türk toplulukları ve konuştukları Türkçe detaylı bir şekilde ayrı bir başlıkta incelenmelidir.

\section{Üsküp Merkez ve Çevresinde Türkçe Konuşan Arnavutlar}

Üsküp'te nüfusun büyük bir oranını kapsayan Arnavutların birçoğu Arnavutçanın yanında Türkçe de konuşmaktadır. Yapmış olduğumuz saha çalışmasında Üsküp'e bağlı, Arnavutların yaşadığı Luboten, Hasanbeg, Saray, Studeniçan ve Yukarı Batinsi köylerinde birçok Arnavut'un Türkçe konuştuğu tespit edilmiş, bunlardan bazıları kaynak kişi olarak alınmış ve kendilerinden derleme yapılmıştır. Aynı şekilde Üsküp merkezde de Türkçe konuşan birçok Arnavut tespit edilmiştir.

Bazı Arnavut aileleri "Türkçe biliyor musunuz?" sorusuna "Elhamdülillah Türk'üz" demektedirler. Bu, İslam dinindeki "Elhamdülillah Müslümanız" deyişiyle özdeşleşmiştir. Burada yaşayan bazı Türk, Yetişkinleri Makedonca Konuşan Türk Toplulukları, Arnavut halk için Türk olmak ya da Türkçe bilmek, Müslüman olmak kadar kutsal bir durumdur. Bu söylemin bir sebebi, Türkçe öğrenmenin zenginlik, asillik ve Müslümanlık olarak görülmesidir. Yukarıda da bahsettiğimiz gibi Türkçe bilen "Kasabalıdır". Türkçe bilmeyen ise yerli Üsküp halkının deyişiyle "Köylüdür". Arnavut ailelerinin bazılarında Türkçenin evlerde konuşularak yeni nesilde yaşatılmak istenmesinin bir diğer sebebi de ailede en az bir kişinin; anne ya da babanın Türk olmasıdır. Türk olan anne ya da baba, evde Türkçe konuşulmasını sağlamış, Türk televizyon kanallarının izlenmesi için çocuklarını teşvik etmiştir. Öyle ki saha çalışmasında gittiğimiz kaynak kişilerin evlerinde Türk televizyon kanallarından başka kanalların izlenmediğini gördük. Bazı aileler evde Türkçeden başka bir dilin konuşulmadığını vurgulamışlardır. Türk, Yetişkinlerim Makedonca konuşan Türk toplulukları ve Arnavut kesimin Üsküp'te yaşayarak Türkçenin yeni nesillerce konuşulması için bu kadar çabalaması bizi epey sevindirdi.

Teknolojinin gelişmesiyle birlikte görsel, işitsel öğeler göz önüne serilmiş ve böylece dil öğrenmek daha da kolaylaşmıştır. Görsel ve işitsel öğelerin en başında video, film ve diziler gelmektedir. İnsanlar bir diziyi izlerken dizinin her bölümünü merak ve heyecanla beklemektedirler. Bu merak ve heyecan onlarda dil öğreniminin kolayca gerçekleşmesine yardımcı olur. Ayrıca 15-20 yaş grubundaki gençler dizi repliklerini taklit yoluyla ezberlemekte ve bazı Türkçe kalıp ifadeleri zihninde saklayıp yeri geldiği zaman günlük hayatta kullanabilmektedir. Hatta bu replikler sokak aralarındaki duvarlarda yerlerini almaktadır.

\section{Türk Televizyon Kanallarını İzlemenin Türkçe Öğrenimine Katkısı}

Teknolojinin gelişmesiyle birlikte Türk televizyon dizi, film ve program yapımında artışlar olmaya başlamıştır. Dizi, film ve belgeseller son zamanlarda Türk 
devlet politikası haline gelmektedir.

"2000'li yıllarda Türkiye'de uygulanan küresel pazar politikalarının ve medya sektöründe yaşanan canlanmanın en önemli yansımalarından biri dizi filmler olmuştur. Kısa sürede kendi başına bir sektöre dönüşecek kadar hızlı büyüyen ve uluslararası bir boyut kazanan yerli yapım diziler bir yandan ulusal televizyon kanallarında en fazla izlenen popüler programlar hâline gelirken diğer yandan ulusal sınırları aşarak ihraç edilen yapımlara dönüşmüştür. Türkiye'de her yıl yüzün üzerinde dizi üretilmektedir. Çekilen her 4 diziden 3'ü ise 103 ülkeye ihraç edilmektedir. Başta Ortadoğu ve Balkan ülkeleri olmak üzere ABD, Şili, Ekvator, Çin, Rusya, Pakistan gibi dünyanın dört bir yanına pazarlanan Türk dizilerinin hali hazırda 400 milyon izleyicisi olduğu öngörülmektedir. Bu rakamlar Türkiye'yi $A B D^{\prime}$ den sonra dünyaya dizi ihraç eden ikinci ülke konumuna getirmektedir" (Öztürk ve Atik, 2016, s. 66).

Türk film ve dizileri sayesinde Türk dil, kültür, yaşayış, adet, gelenek ve göreneklerine olan merak artmış, Türkçe cezbeden bir dil haline gelmiştir.

Türkiye'deki dizi sektörü, Kuzey Makedonya'nın başkenti olan Üsküp’te ve diğer şehirlerinde, ayrıca diğer Balkan ülkelerinde de yaygın bir şekilde takip edilmektedir. 15 ve 20 yaşları arasındaki bazı Türk, Yetişkinleri Makedonca konuşun Türk toplulukları, Arnavut gençler çeşitli Türk dizilerini izlemekte ve Standart Türkiye Türkçesine yakın bir dille Türkçeyi konuşmaktadırlar. Bu kanıya saha çaışmasında yaptığımız gözlemler neticesinde vardık. Bu da Türkçenin keyifle öğrenildiğinin bir delili olarak gözler önüne serilmektedir. Son zamanlarda genç nesil; "Hercai, Kimse Bilmez, Afili Aşk, Erkenci Kuş, Bir Zamanlar Çukurova, Sen Anlat Karadeniz, Çukur, Tozkoparan, Diriliş Ertuğrul” gibi popüler dizileri izlemektedir.

Kuzey Makedonya Cumhuriyeti Türk dizilerini satın almaktadır; fakat Türkçenin öğrenilmesine engel olmak için bir yol izlemektedir. Türkiye'den alınan tüm diziler Makedon kanallarında, Makedonca altyazılı verilmek yerine Makedonca dublaj yapılarak yayınlanmaktadır. Yunanistan, Bulgaristan'dan alınan dizilerde ise Makedonca dublaj yapılmadığı, Makedonca altyazı verilerek dizilerin yayınlandığı görülmüştür. Bu, Kuzey Makedonya Cumhuriyeti'nin Türkçenin öğrenilmemesi için izlediği en büyük düşmanca politikalardan biridir. Önceden Türk dizileri de dublajsız, orijinal haliyle yayınlanmaktayken günümüzde dublajlı haliyle yayınlanmaktadır. Bunun sebebi, dizilerin Türkçe orijinal haliyle verildiğinde genç nesil arasında konuşulmaya ve yaygınlaşmaya başlaması ve bunun Kuzey Makedonya devletinin hoşuna gitmeyen bir durum olmasıdır.

Türk dilini çocuklarına, torunlarına öğretmek isteyen bilinçli Türk, Yetişkinleri Makedonca konuşun Türk toplulukları ve Arnavut aileleri Türk dizilerini Make- 
donca dublajlı izlemek yerine uluslararası kanalların yayınlandığı uydu alıcısı satın almakta, Türk dizi ve filmlerini orijinal haliyle izlemektedir. Bazı ailelere Türkiye devleti tarafından uydu alıcısı dağıtılmıştır. Tüm Türk, Yetişkinleri Makedonca konuşun Türk toplulukları ve Arnavut aileler uluslararası kanalların yayınlandığı uydu alıcısını satın alamadığından Türkçe, belli bir Müslüman kesimin konuştuğu dil olarak kalmaktadır. Müslüman genç neslin birçoğu Türk dili ve Türk kültüründen mahrum olmaktadır.

Türkiye Cumhuriyeti olarak Türkçe öğreniminin yaygınlaşması ve Türkçenin etki alanının genişlemesi için dizi sektörüne önem vermeye bununla birlikte dizi üretimi ve ihracatına devam etmeliyiz. Böylece Türkçe, zaten konuşulmakta olan başta Kuzey Makedonya Cumhuriyeti'nin başkenti Üsküp ve civarı olmak üzere diğer Balkan ülkeleri ve Türkistan Türk Cumhuriyetlerinin yanında Orta Doğu ülkelerine, Avrupa'ya ve diğer kıtalardaki ülkelere yayılacak, Türk diliyle birlikte Türk kültürünün etki alanı genişleyecektir.

\section{Sonuç}

Üsküp, 1912 Sırp işgaline kadar Türk oranının en yüksek olduğu ve Türkçenin tarım ve ticaret vasıtasıyla yaygınca konuşulduğu bir şehir olma özelliği taşımasına rağmen 1912 Sırp işgali ve 1948 Yücel Olayıyla epey Türk göçü vermiştir. Üsküp'te kalan Türk, Yetişkinleri Makedonca konuşan Türk toplulukları ve bazı Arnavutlar Türkçenin Müslüman kesim arasında konuşulmaya devam etmesi için ellerinden geleni yapmaktadır.

Üsküp'teki "Tefeyyüz" isimli ilköğretim okulu, 1884 yılından itibaren 9 yıllık Türkçe eğitim vermekte ve Türkçenin ayakta durabilmesi için faaliyetlerine hâlâ tüm gücüyle devam etmektedir. Günümüzde de Türkçe eğitim veren okulların en başında olmayı sürdürmektedir.

Türkler ve Arnavutların yanında yetişkinleri Makedonca konuşan ve kendilerini Türk olarak kabul eden topluluk, Türkçe eğitim alabilmek için yıllarca mücadele vermiş ve bu mücadelenin karşılığını köylerinde Makedonca eğitim veren okulların 9 yıllık Türkçe eğitim veren okullara dönüştürülmesiyle almışlardır. Günümüzde köylerindeki okullarda eğitim Türkçe olarak verilmektedir.

Türk dizilerinin Türkçe öğretimindeki büyük katkısı Üsküp’te karşımıza çıkmıştır. Özellikle 15-20 yaş grubu arasındaki genç nesil, popüler Türk dizilerini takip etmekte ve Türkçeyi, Standart Türkiye Türkçesine yakın bir dille konuşmaktadır.

Kuzey Makedonya Cumhuriyeti'nin Türkçenin konuşulmasını ve yaygınlaş- 
masını engellemek amacıyla Türk dizilerini Makedonca dublaj yaparak yayınlamasına karşılık, bizim de Türkiye Cumhuriyeti olarak Türk dizi sektörünü destekleyip, dizilerin Türkçe haliyle yayınlanması, yayınlandıkları ülkenin diliyle altyazı verilmesi için çeşitli öneriler getirmemiz gerekmektedir.

\section{Kaynakça}

Abbas, Z. B. (1998). Makedonya'da Türklerin Eğitimi. Balkan Ülkelerinde Türkçe Eğitim ve Yayın Hayatı Bilgi Şöleni (20-24 Nisan 1998), Ankara, Türk Dil Kurumu Yayınları, 283-300.

Ago, A. (1996). Makedonya'da Türk Halkının Ana dili Üzerinde Öğretim-Eğitim ve Sorunları. Sesler, (302), 5-14.

Ahmed, O. (2014). Üsküp Türk Ağzında Kip Ekleri. TÜRÜK, (4), 1-36.

Asimov, M. (1983). Kosova Vilayetindeki İptidaiyeler. Çevren, (57), 5567.

Çelik, B. (2013). Dağılan Yugoslavya Sonrası Kosova ve Makedonya Türkleri. İstanbul: Gürer Yayınları.

Bugariç, R. (1998). Üsküp Ağzında Türkçenin İzleri, Türkçenin Zenginliği. Tarih Boyunca Türk Dili Bilgi Şöleni (13-14 Mayıs 1997), TBMM Kültür, Sanat ve Yayın Kurulu Yayınları, 181-185.

Eren, İ. (1968). Üsküp-Kosova Vilayeti Sanayi Mektebi. Sesler, (29), 4147.

Hamzaoğlu, Y. (2000). Balkan Türklüğü. Ankara: T.C. Kültür Bakanlığı Yayınları.

Hasan, H. (1998). Makedonya'da Türkçe Eğitim ve Abdülhakim ve Hikmet Doğan. Üsküp: Birlik Yayınları.

Hoca, F. (2011). Osmanlı'nın Son Döneminde Makedonya'da Türkçe Eğitimi. Makedonya'da Osmanlı Eserleri, IV. Uluslararası Türkçe Eğitim Günü Sempozyumu ve Sergisi, Üsküp: MATÜSiTEB, 101-111.

İnbaşı, M., Kul, E. (2018). Balkanlarda Bir Türk Şehri Üsküp Fetihten XVIII. Yüzyıla Kadar. Ankara: Türk Tarih Kurumu Yayınları.

Karakuş, E. (2018). Yahya Kemal ve Üsküp. İstanbul: İstanbul Fetih Cemiyeti Yayınları. 
Kaya, F. (1999). Şafak Sökerken, Tefeyyüz ve Edebiyatımız. Üsküp: Yeni Balkan Yayınları.

Kodaman, B. (1991). Abdülhamid Dönemi Eğitim Sistemi. Ankara: Türk Tarih Kurumu.

Oran, B. (1993). Balkan Müslümanlarında Dinsel ve Ulusal Kimlik (Yunanistan, Bulgaristan, Makedonya ve Kosova Üzerine Karşılaştırmalı Bir Inceleme). Ankara Üniversitesi Siyasal Bilgiler Fakültesi Dergisi, 48(01), 109-120.

Öztürk, M., Atik, A. (2016). Ulusal Pazarlardan Küresel Pazarlara Uzanan Süreçte Türk Dilinin Gelişimi. Maltepe Üniversitesi Iletişim Fakültesi Dergisi, 3(2), 66-82.

Salih Âsım Bey. (2004). Üsküp Tarihi ve Civarı. Sadeleştiren: Süleyman Baki, İstanbul: Rumeli Araştırmaları Merkezi Yayınları.

Tefeyyüz (2019)."http://tefeyyuz.edu.mk/index-tr.html” Erişim Tarihi: [29.09.2019].

Tufan, M. (1996). Makedonya'da Türk Ahalinin Göçleri, Sesler, (306307), 5-14.

Zdraveya, M. (1983). Osmanlı İdaresi Zamanında Üsküp. Sesler, (175), 93-97. 